\title{
A new species of the lowland Oligosarcus Günther species group (Teleostei: Ostariophysi: Characidae)
}

\author{
Naércio Aquino Menezes ${ }^{1}$ and Alexandre Cunha Ribeiro ${ }^{2}$
}

\begin{abstract}
A new characid species is described from the rio Jacuí basin, a coastal drainage from southern Brazil. It is morphologically most similar to its sympatric congeners Oligosarcus jenynsii and $O$. jacuiensis, but can be distinguished from both species in having the interorbital region wider and the pectoral fin shorter and additionally from $O$. jenynsii in having a smaller orbital diameter.

Uma nova espécie de caracídeo é descrita da bacia do rio Jacuí, uma drenagem costeira do Sul do Brasil. É morfologicamente mais semelhante as espécies congêneres simpátricas Oligosarcus jenynsii e $O$. jacuiensis, mas pode ser distinguida de ambas as espécies por possuir a região interorbital mais larga e a nadadeira peitoral mais curta e adicionalmente de $O$. jenynsii por possui o diâmetro orbital menor.
\end{abstract}

Keywords: Freshwater fish, Neotropical, South America, Systematics, Taxonomy.

\section{Introduction}

In addition to Oligosarcus robustus Menezes, 1969, O. jenynsii (Günther, 1864 ), and O. jacuiensis Menezes \& Ribeiro, 2010 sympatric species described from the coastal plains of Rio Grande do Sul, Brazil and belonging to the lowland species component of the genus (Menezes, 1988; Ribeiro \& Menezes, 2015), another new species was recently discovered from the same area raising to four the number of sympatric species within the rio Jacuí basin, a rather unusual occurrence considering the allopatric distribution of most of the remaining species.

The Oligosarcus species from lowland coastal areas have a very similar body shape and can be told apart through morphological features especially meristics and morphometrics included in the new species description and compared with those of the already described species in the discussion in order to depict closest similarities.

\section{Material and Methods}

Specimens are from the Museu de Ciências e Tecnologia, Pontifícia Universidade Católica do Rio Grande do Sul, Porto Alegre (MCP) and Museu de Zoologia, Universidade de São Paulo, São Paulo (MZUSP). Morphometric and meristic data were taken with digital calipers and recorded to tenths of a millimeter and follow Fink \& Weitzman (1974) and Menezes (1987). In the species descriptions the range of meristic characters is presented first, followed by the mean of the sample and by counts of holotype in parentheses. The abbreviation SL corresponds to standard length. Comparative material examined is the same of Menezes \& Ribeiro (2010). A nearly conical tooth that appears in the species description is characterized by having only a vestigial lateral cusp.

\section{Results}

\section{Oligosarcus varii, new species}

urn:1sid:zoobank.org:act:F3691EC0-CB13-4F5C-B2A8607DBC1DDF12

Figs. 1-4

Holotype. MCP 31148, female, 184.0 mm SL, Brazil, Rio Grande do Sul, São Marcos, rio Jacuí basin, rio São Marcos near to hydroeletric plant PCH rio São Marcos, $29^{\circ} 02^{\prime} 13^{\prime \prime} \mathrm{S}$ 51 ${ }^{\circ} 05^{\prime} 39^{\prime}$ W, 13 Sep 2002, A. R. Cardoso \& V. A. Bertaco.

Paratypes. MCP 48172, 3, 175.0-183.0 mm SL, all females, MZUSP 115381, 2, 181.0-197.0 mm SL, both females, collected with holotype.

${ }^{1}$ Museu de Zoologia, Universidade de São Paulo, Caixa Postal 42.494, 04218-970 São Paulo, SP, Brazil.naercio@usp.br(corresponding author)

${ }^{2}$ Departamento de Zoologia, Instituto de Biociências, Universidade Federal de Mato Grosso, Avenida Fernando Corrêa da Costa 2.367, 78060-900 Cuiabá, MT, Brazil. alexandrecunharibeiro@gmail.com 
Diagnosis. The new species is distinguished from all its congeners by the number of lateral-line scales (56-62 vs. less than 55 or higher than 69), except for Oligosarcus jenynsii (54-65), O. perdido Ribeiro, Cavallaro \& Froehlich, 2007 (61-63) and O. jacuiensis (55-65). Oligosarcus varii has in common with $O$. jenynsii, $O$. jacuiensis and $O$. perdido the absence of a foramen on the premaxilla (fig. 2a in Menezes \& Ribeiro, 2010) and in this regard differs from O. acutirostris Menezes, 1987 and $O$. hepsetus (Cuvier, 1829) in which the foramen is present (fig. 2b in Menezes \& Ribeiro, 2010). It can be further distinguished from $O$. acutirostris in having 2124 anal-fin rays (vs. 25-30). Oligosarcus varii differs from $O$. jenynsii in having the interorbital width $25-26.5 \%$ of HL (vs. 18.4-24.4\% of HL), the horizontal diameter of the eye $22-23.5 \%$ of HL (vs. $25-34 \%$ of HL) and the tip of the pectoral fin distant from the vertical through the pelvicfin origin (vs. tip of pectoral fin reaching and extending slightly beyond the vertical through the pelvic-fin origin). Oligosarcus varii differs from $O$. jacuiensis in having the least interorbital width $25-26.5 \%$ of HL (vs. $20-24.5 \%$ of HL). Oligosarcus varii differs from $O$. perdido in having 21-24 longitudinal scale rows around the caudal peduncle (vs. 18-21), 9 longitudinal scale rows from analfin origin to lateral line (vs. 6-8) and 11-12 longitudinal scale rows from dorsal-fin origin to lateral line (vs. 7-11). Oligosarcus varii differs from $O$. itau Mirande, Aguilera \& Azpelicueta, 2011, O. platensis (Messner, 1962) and $O$. amome Almirón, Casciotta, Piálek, Doubnerová \& Říčan, 2015 , that have two rows of premaxillary teeth and of pentacuspidate teeth on the dentary.

Description. Morphometrics in Table 1. Body moderately large, 181-197 mm SL. Head and body profile convex with slight depression at occipital region, concave above caudal peduncle; ventral body profile slightly more convex than dorsal, also concave at lower portion of caudal peduncle.
Snout conical, larger than orbital diameter; lower jaw slightly shorter that upper jaw and first two caniniform premaxillary teeth accommodated into two small furrows when mouth is closed. Maxillary widening gradually towards posterior end, its posterior tip not extending beyond vertical crossing posterior edge of orbit; single row of 23-25, 23.8 (24) nearly conical maxillary teeth. Premaxilla with one anterior and one posterior caniniform teeth, and 3 to 4, 3.5 (4) nearly conical teeth aligned with caniniform teeth. Dentary bearing an anterior canine, followed by three conical teeth about equally developed and posterior row of 13-18, 15.1 (13) nearly conical teeth. Ectopterygoid with 12-13, 12.5 (13) nearly conical teeth. All nearly conical teeth on premaxilla, maxilla, dentary and ectopterygoid with vestigial lateral cusps, anterior edge of teeth convex and posterior edge concave, their tips pointing backward. 24-25, 24.3 (24) gill rakers on epibranchial and ceratobranchial portions of first gill arch.

Dorsal-fin origin closer to caudal-fin base than to tip of snout, dorsal-fin rays ii,9 in all specimens, including holotype. Adipose fin present. Anal-fin rays iv-v,21-24, 22.6 (24), fin origin slightly posterior to vertical crossing base of last dorsal-fin ray. Moderately developed anterior anal-fin lobe including anterior unbranched rays and first 8 or 9 branched rays. Pectoral-fin rays i,11-14, 12.6 (12), tip of longest rays far distant from pelvic-fin origin. Pelvic-fin rays i,7 in all specimens, including holotype; tip of longest rays reaching anterior border of anus.

Lateral line complete, perforated scales 56-62, 58.5 (59); 11-12, 11.3 (11) horizontal scale rows from dorsalfin origin to lateral line, 9 from anal-fin origin to lateral line in all specimens, including holotype; 21-24, 22.5 (24) horizontal scale rows around caudal peduncle; 24-26, 24.5 (23) scales from tip of occipital to dorsal-fin origin; scale row along both sides of anal-fin base extending to about base of $11^{\text {th }}$ or $12^{\text {th }}$ branched anal-fin ray.

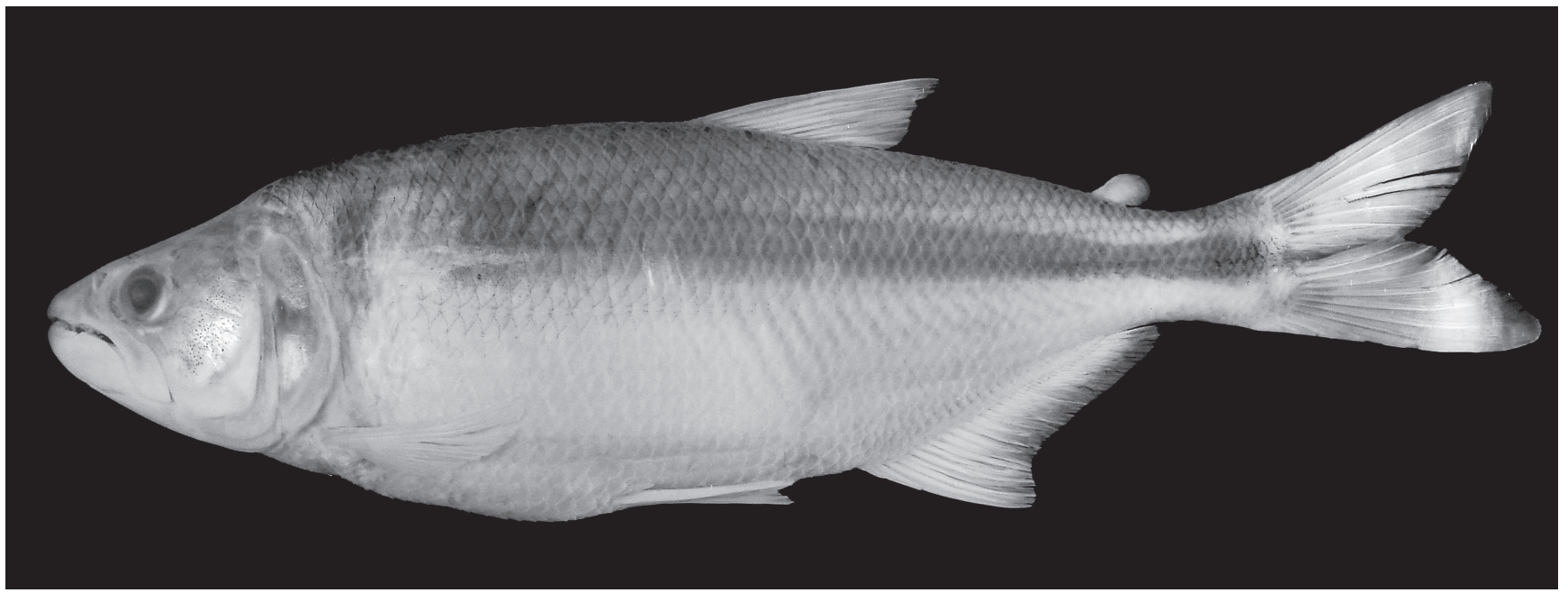

Fig. 1. Oligosarcus varii, holotype, MCP 31148, female, $184 \mathrm{~mm}$ SL, Brazil, Rio Grande do Sul, São Marcos, rio Jacuí basin. 


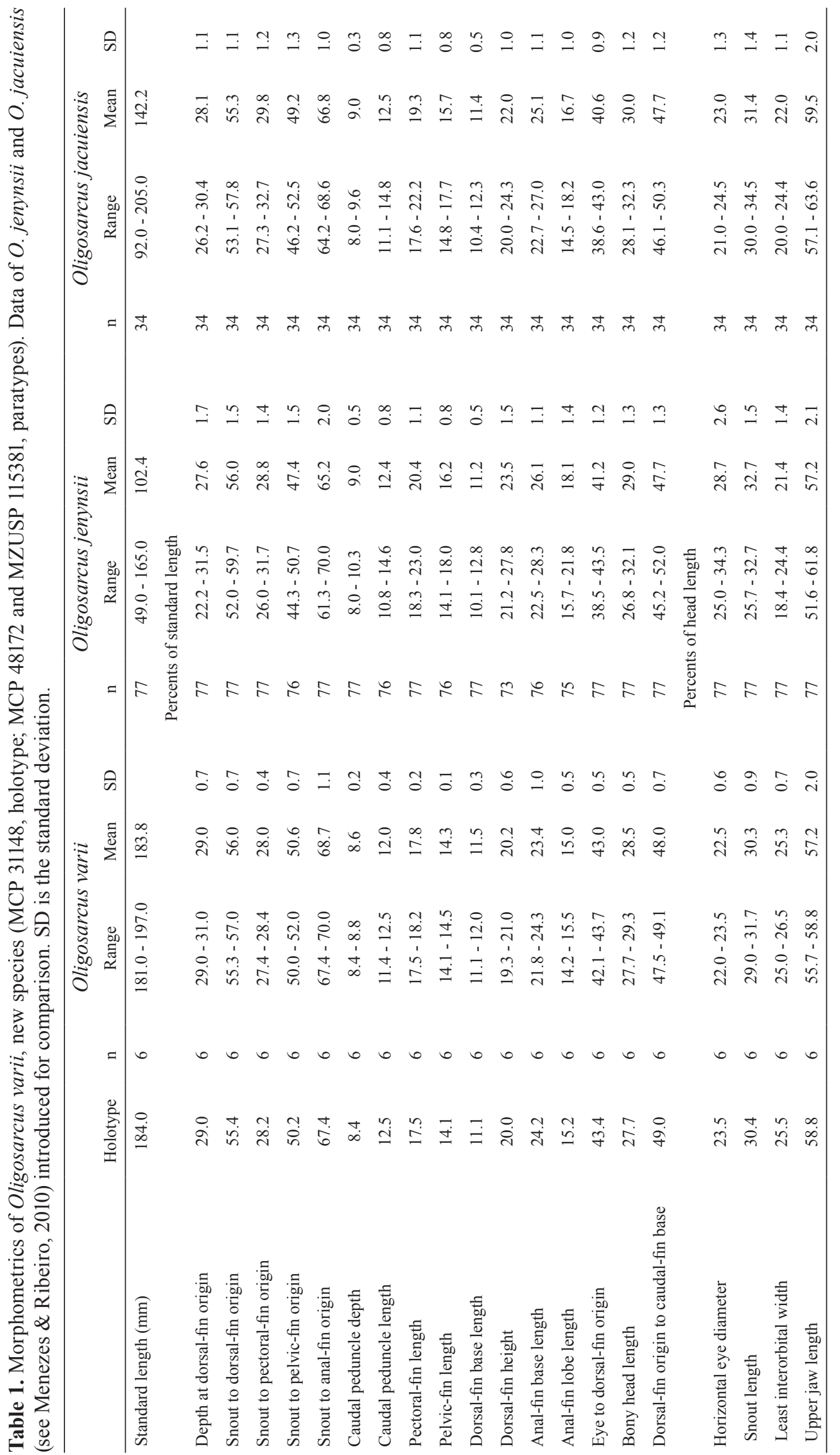




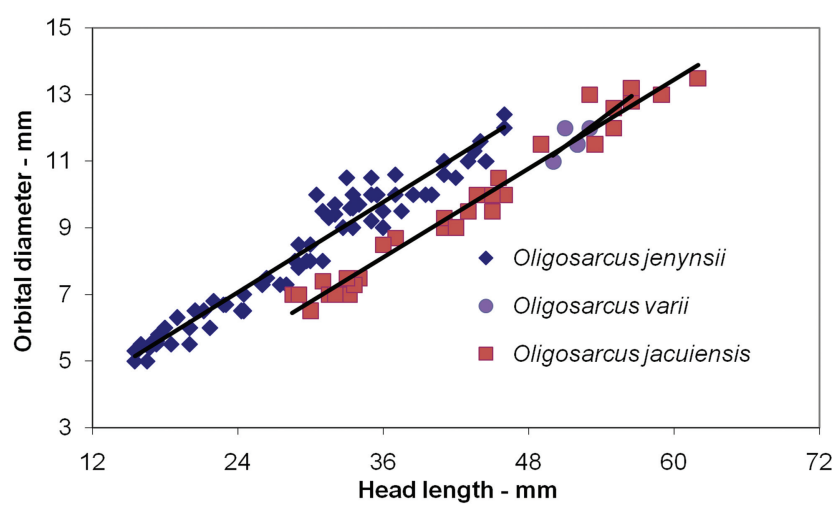

Fig. 2. Horizontal orbital diameter as a function of head length for Oligosarcus varii. Oligosarcus jenynsii and $O$. jacuiensis introduced for comparisons.

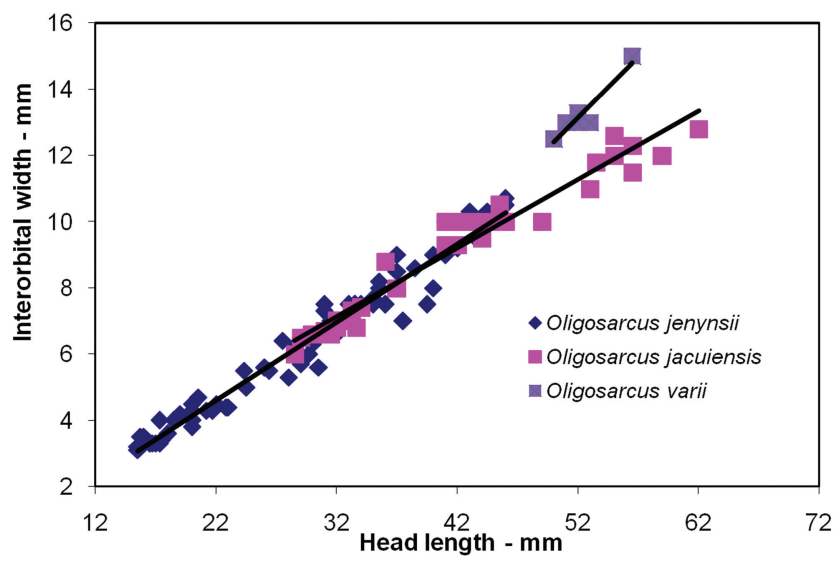

Fig. 3. Least interorbital width as a function of head length for Oligosarcus varii. Oligosarcus jenynsii and O. jacuiensis introduced for comparisons.

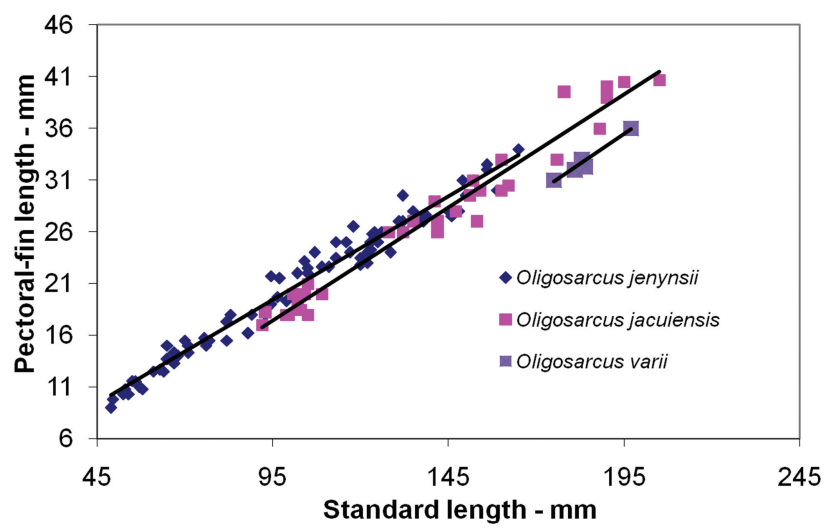

Fig. 4. Pectoral-fin length as a function of standard length for Oligosarcus varii. Oligosarcus jenynsii and O. jacuiensis introduced for comparions.

Color in alcohol. Body pale yellow darker dorsally than ventrally. Dark chromatophores especially concentrated on free edge of scales. Dorsal portion of head and snout darker, dark coloration extending as a narrow stripe over anterior two thirds of maxillary. Lateral head and opercular bones with scattered dark chromatophores, ventral portion of opercle darker than dorsal. Dark ovalshaped spot near middle inner border of opercle. Tip of lower jaw dark, this pigmentation extending as a narrow stripe to about half the length of upper lateral portion of lower jaw. Vertically elongate dark humeral blotch wider dorsally and tapering ventrally covering second, third and fourth anterior perforated scales of lateral line. Dark lateral body stripe extending from dorsal portion of opercle across dark humeral blotch to caudal-fin base narrower anterior to caudal peduncle, expanding dorsally and ventrally through posterior portion of caudal peduncle and caudal-fin base and extending over median caudal-fin rays, sometimes obscured by guanine and becoming silvery. All fins pale with scattered dark chromatophores especially on dorsal and caudal fins.

Distribution. Known from the type locality in the rio Jacuí basin in Rio Grande do Sul, Brazil (Fig. 5).

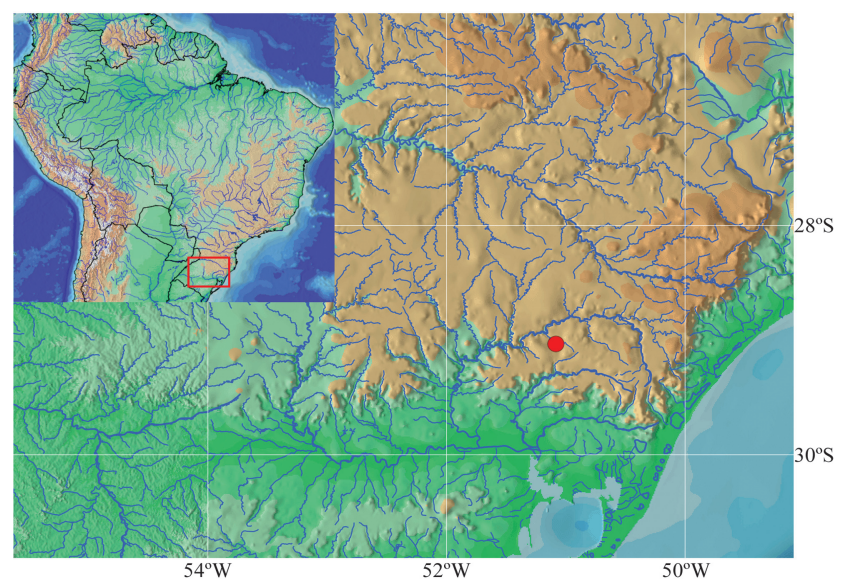

Fig. 5. Rio Jacuí basin showing the collecting site and type locality (red dot) of Oligosarcus varii.

Etymology. Oligosarcus varii is named after Richard P. Vari for his outstanding contribution to the knowledge of South American freshwater fishes.

Conservation status. Oligosarcus varii is only known from its type locality, but it probably has a more widely distribution within the Guaíba basin. Threats were not noticed in the area and the species would be classified as Least Concern (LC) according to the International Union for Conservation of Nature (IUCN Standards and Petitons Subcommittee, 2014).

\section{Discussion}

The six mature females specimens that are considered herein to belong to a new species present clear-cut morphological differences in relation to the hitherto known species of Oligosarcus. None of the characters that have been traditionally used to distinguish the species of this genus are sexually dimorphic so that the possibility that 
the differences found are related to sex can be eliminated. Also the differences between Oligosarcus varii and its most morphologically similar species $(O$. jenynsii and $O$. jacuiensis) are based on specimens of comparable sizes.

Taking into consideration all the known species of Oligosarcus, $O$. varii falls within the group characterized by the presence of 56-62 perforated lateral line scales (vs. 36-55 or 69-85 in the remaining species) and including $O$. jenynsii and $O$. jacuiensis. Meristics are not useful to distinguish these three species among themselves. The differences concerning the number of maxillary and posterior dentary teeth can be neglected because the number of teeth on those bones are known to increase in number with an increase in standard length (Menezes \& Ribeiro, 2010: 650) and Oligosarcus varii is represented only by adult specimens. Nonetheless $O$. varii can be distinguished from both $O$. jenynsii and $O$. jacuiensis in having the interorbital wider (Fig. 3) and the pectoral fin shorter (Fig. 4) and additionally from $O$. jenynsii in having a smaller orbital diameter relative to the head length (Fig. 2).

Menezes (1988) and Ribeiro \& Menezes (2015) discuss that, contrary to upland areas, marked by strong allopatry, high degree of sympatry, alternatively, is observed in lowland components of the genera. Oligosarcus jenynsii, $O$. robustus and $O$. jacuiensis are sympatric (as well as $O$. varii described herein) along the coastal plain of southern Brazil. However, this set of species are not necessarily syntopic (as exemplified by Ribeiro \& Menezes with respect to $O$. pintoi and $O$. paranensis). According to Ribeiro \& Menezes (2015) sympatry among closely related species are often referred to as evidence of recent faunistic restructuring, being for example, the result of recent dispersion. The phylogenetic affinities of $O$. varii have not been investigated, but clearly belongs to Ribeiro \& Menezes' large clade 10 that includes relatively large piscivourous species distributed mostly along the lowland areas of Southern South America (Ribeiro \& Menezes, 2015: 68, fig. 19). Future phylogeographic studies focused on modern molecular techniques could help depicting the time interval and the sequence of historical events that shaped the present day distribution among populations in this set of sympatric Oligosarcus species.

\section{Acknowledgements}

Thanks are due to Carlos Alberto S. de Lucena and Zilda Margarete S. de Lucena (PUCRS) for making available the specimens examined in this work. Fernando Dagosta (MZUSP) provided assistance for the elaboration of the geographical distribution map of the species. Financial support was received by NAM from $\mathrm{CNPq}$ (Process \# 300942/2009) and FAPESP through the project South American Characiform Inventory (Process \# 2011/50282-7) and by ACR from CNPq (Processes \# 140488/2004-9, 010247/2010-6, 401818/2010-1), FAPEMAT (Processes \# $447441 / 2009$ and 572844/2008).

\section{References}

Almirón, A., J. Casciotta, L. Piálek, K. Doubnerová \& O. Říčan. 2015. Oligosarcus amome (Ostariophysi: Characidae), a new species from the río Uruguay basin, Misiones, Argentina. Zootaxa, 3915: 581-590.

Cuvier, G. 1829. Le Règne Animal distribué d' après son organisation (Nouvelle édition). Poissons, 2: 122-406.

Fink, W. L. \& S. H. Weitzman. 1974. The so-called Cheirodontin fishes of Central America with descriptions of two new species (Pisces: Characidae). Washington, D. C., Smithsonian Institution Press, 46p. (Smithsonian Contributions to Zoology, no. 172).

Günther, A. 1864. Catalogue of the species in the British Museum. $455 \mathrm{p}$.

International Union for Conservation of Nature (IUCN) Standards and Petitions Subcommittee. 2014. Guidelines for using the IUCN Red List Categories and Criteria. Version 11. Prepared by the Standards and Petitions Subcommittee. Available from http://www.iucnredlist.org/ documents/RedListGuidelines.pdf. (12 August 2015).

Menezes, N. A. 1969. Systematics and evolution of the tribe Acestrorhynchini (Pisces: Characidae). Arquivos de Zoologia, São Paulo, 18(1-2): 1-150.

Menezes, N. A. 1987. Três espécies novas de Oligosarcus Günther, 1864 e redefinição taxonômica das demais espécies do gênero (Osteichthyes, Teleostei, Characidae). Boletim de Zoologia da Universidade de São Paulo, 11: 1-39.

Menezes, N. A. 1988. Implications of the distribution patterns of the species of Oligosarcus (Teleostei, Characidae) from central and southern South America. Pp. 295-304. In: Heyer, W. R. \& P. E. Vanzolini (Eds.). Proceedings of a Workshop on Neotropical Distribution Patterns. Rio de Janeiro, Academia Brasileira de Ciências.

Menezes, N. A. \& A. C. Ribeiro. 2010. Oligosarcus jacuiensis (Characiformes: Characidae), a new species from the Uruguay and Jacuí River basins, southern Brazil. Neotropical Ichthyology, 8: 649-653.

Messner, E. 1962. Lista de los peces Tetragonopterinae (fam. Characidae) del Uruguay. Boletin de la Asociación Latinoamericana de Ictiólogos y Herpetólogos, 2: 4-5.

Mirande, J. M., G. Aguilera \& M. de la M. Azpelicueta. 2011. A threatened new speciesd of Oligosarcus and its phylogenetic relationships with comments of Astyanacinus (Teleostei: Characidae). Zootaxa, 2994: 1-20.

Ribeiro, A. C., M. R. Cavallaro \& O. Froelich. 2007. Oligosarcus perdido (Characiformes, Characidae), a new species of freshwater fish from Serra da Bodoquena, upper Paraguay basin, Brazil. Zootaxa, 1560: 43-53.

Ribeiro, A. C. \& N. A. Menezes. 2015. Phylogenetic relationships of the species and biogeography of the characid genus Oligosarcus Günther, 1864 (Ostariophysi, Characiformes, Characidae). Zootaxa, 3949: 41-81. 
